\title{
High glucose-induced impairment in insulin secretion is associated with reduction in islet glucokinase in a mouse model of susceptibility to islet dysfunction
}

\author{
Suwattanee Kooptiwut, Melkam Kebede, Sakeneh Zraika, Sherley Visinoni, Kathryn \\ Aston-Mourney, Jenny Favaloro, Chris Tikellis ${ }^{1}$, Merlin C Thomas ${ }^{1}$, Josephine M Forbes ${ }^{1}$, \\ Mark E Cooper ${ }^{1}$, Marjorie Dunlop, Joseph Proietto and Sofianos Andrikopoulos
}

University of Melbourne, Department of Medicine ( $\mathrm{AH} / \mathrm{NH})$, Heidelberg Repatriation Hospital, 300 Waterdale Road, Heidelberg Heights, Victoria 3081 , Australia

${ }^{1}$ Baker Heart Research Institute, Melbourne, Victoria 3004, Australia

(Requests for offprints should be addressed to S Andrikopoulos, Email: sof @unimelb.edu.au)

\begin{abstract}
Type 2 diabetes is characterized by islet dysfunction resulting in hyperglycemia, which can then lead to further deterioration in islet function. A possible mechanism for hyperglycemia-induced islet dysfunction is the accumulation of advanced glycation end products (AGE). The DBA/2 mouse develops pancreatic islet dysfunction when exposed to a high glucose environment and/or obesity-induced insulin resistance. To determine the biochemical cause of dysfunction, DBA/2 and C57BL/6 control islets were incubated in $11.1 \mathrm{mM}$ or $40 \mathrm{mM}$ glucose in the absence or presence of the AGE inhibitor aminoguanidine (AG) for 10 days. Basal ( $2.8 \mathrm{mM}$ glucose) insulin release was increased in both DBA/2 and C57BL/6 islets incubated with $40 \mathrm{mM}$ vs $11.1 \mathrm{mM}$ glucose for 10 days. Chronic exposure to hyperglycemia decreased glucose $(20 \mathrm{mM})$-stimulated insulin secretion in DBA/2 but not in C57BL/6 islets. AG significantly increased fold-induced insulin release in high glucose cultured DBA/2 mouse islets, but did not affect C57BL/6 islet function. DBA/2 islet glucokinase was significantly reduced following $40 \mathrm{mM}$ glucose culture, compared with $11.1 \mathrm{mM}$ glucose cultured DBA/2 islets and $40 \mathrm{mM}$ glucose cultured C57BL/6 islets. Incubation of islets with AG resulted in a normalization of DBA/2 islet glucokinase levels. In conclusion, chronic high glucose-induced increases in AGE can result in islet dysfunction and this is associated with reduced glucokinase levels in a mouse model with susceptibility to islet failure.
\end{abstract}

Journal of Molecular Endocrinology (2005) 35, 39-48

\section{Introduction}

Reduced glucose-mediated insulin release is a characteristic feature of type 2 diabetes resulting in hyperglycemia (Porte 1991). Furthermore, both in vivo (Leahy et al. 1987, Bedoya \& Jeanrenaud 1991) and in vitro (Davalli et al. 1991, Robertson et al. 1992) studies have shown that hyperglycemia itself can activate pathways which diminish glucose-mediated insulin release. Thus, this has the possibility of creating a feedforward cycle of increasing plasma glucose levels leading to impaired insulin secretory function, further worsening hyperglycemia.

Although high glucose-induced impairment in insulin secretion is well recognized, the mechanisms causing this phenomenon are not well understood. For example, it has been proposed that chronic high-glucose-induced impairment in $\beta$-cell function can result from ' $\beta$-cell exhaustion' (Sako \& Grill 1990, Kaiser et al. 1991, Eizirik et al. 1992, Ling et al. 1996,), although this has not been a consistent finding (Davalli et al. 1991). Another possible mechanism is a reduction in insulin gene transcription factors (e.g. PDX-1 and RIPE3bl) leading to decreased $\beta$-cell insulin content (Robertson et al. 1992, Poitout et al. 1996, Moran et al. 1997, Marshak et al. 1999). However in at least one study, reduction of the transcription factor PDX-1 using a specific antisense oligodeoxynucleotide did not lead to decreased insulin levels (Kajimoto et al. 1997).

Advanced glycation end products (AGEs) accumulate in cells and tissues as a result of chronic high glucose exposure and are thought to be an important mechanism in the pathogenesis of diabetic complications (Forbes et al. 2003). It has been proposed that the in vitro accumulation of AGEs may lead to impaired $\beta$-cell function (Matsuoka et al. 1997, Tajiri et al. 1997, Kajimoto et al. 1999, Kaneto et al. 1999). Proposed AGE-related defects in insulin secretion include reduced insulin biosynthesis (Tajiri et al. 1997) as a result of diminished insulin gene promoter activity (Matsuoka et al. 1997) and reduced $\beta$-cell mass (Piercy et al. 1998, Kaneto et al. 1999).

DOl: 10.1677 /ime 1.01720 Online version via http://www.endocrinology-journals.org 
The DBA/2 and the C57BL/KsJ mouse strain, which carries a small portion of the DBA/2 genome (Naggert et al. 1995), have a genetic predisposition to pancreatic islet failure. Islet function is grossly impaired in DBA/2 and C57BL/KsJ mice expressing the $d b / d b$ gene (which results in obesity and insulin resistance as a result of a defective leptin receptor molecule) with an absence of both first and second phase insulin secretion. The hyperglycemia which develops is a consequence of decreased insulin production from a reduction in the islet $\beta$-cell population (Baetens et al. 1978, Leiter et al. 1981, Molina et al. 1984). By contrast, expression of the $d b / d b$ gene on a C57BL/6 genetic background results in marked obesity, insulin resistance, with only mild hyperglycemia and marked hyperinsulinemia (Leiter et al. 1981). Furthermore, when islets from C57BL/KsJ mice are exposed to a high glucose environment by intrasplenic transplantation in syngeneic donors made hyperglycemic by treatment with streptozotocin, they show a depressed rate of cell proliferation and are eliminated within 12 days (Leiter 1987). On the other hand, C57BL/KsJ islets transplanted into normoglycemic donors are retained. Moreover, chronic incubation of DBA/2 mouse islets with glucose concentrations greater than $11 \cdot 1 \mathrm{mM}$ caused diminished glucose-induced insulin secretion (Pehuet-Figoni et al. 1994). These studies highlight the increased susceptibility of islets from the DBA/2 and C57BL/KsJ strains to a chronic high glucose milieu. However, a mechanism for this pancreatic islet failure has not been explored.

The aim of the present study was to investigate differences in early biochemical defects in the failureprone $\mathrm{DBA} / 2$ mouse compared with $\mathrm{C} 57 \mathrm{BL} / 6$ mice using isolated islets cultured in a high glucose environment.

\section{Materials and methods}

\section{Materials}

Collagenase $\mathrm{P}$ was obtained from Boehringer Mannheim (Mannheim, Germany). Culture medium RPMI 1640 with L-glutamine without sodium bicarbonate was obtained from Trace Scientific Ltd (Victoria, Australia). Aminoguanidine was obtained from SigmaAldrich (Australia).

\section{Animals}

Male C57BL/6 and DBA/2 mice were purchased from the Walter and Eliza Hall Institute Animal Research Facility (Kew, Victoria, Australia) and housed in the Department of Medicine Animal Research Facility under a 12 hour light/dark cycle with a standard laboratory non-purified diet containing $77 \%$ of energy as carbohydrate, $20 \%$ protein and $3 \%$ of calories as fat
(Barastock Products, Pakenham, Australia) provided ad libitum unless otherwise stated. All animals were 8-10 weeks of age at the time of study and all procedures described below were approved by the Royal Melbourne Hospital Animal Research Ethics Committee.

\section{Islet isolation and culture}

Pancreatic islets were isolated by collagenase digestion as previously described (Kooptiwut et al. 2002, Zraika et al. 2002). The isolation of the islets was accomplished using a Ficoll gradient and hand picking under a stereomicroscope. Islets were cultured in RPMI 1640 containing either $11.1 \mathrm{mM}$ or $40 \mathrm{mM}$ glucose with $10 \%$ heat inactivated fetal calf serum, $100 \mathrm{U} / \mathrm{ml}$ penicillin, and $100 \mu \mathrm{g} / \mathrm{ml}$ streptomycin at $37^{\circ} \mathrm{C}$ in humidified air $5 \%$ $\mathrm{CO}_{2}$ for 10 days, with the media being changed every second day. Aminoguanidine at a final concentration of $1 \mathrm{mM}$ was added to the media of half of the islets incubated with $40 \mathrm{mM}$ glucose for 10 days.

\section{Insulin secretion assay}

Islets were washed twice in Krebs Ringer Bicarbonate Buffer (KRB) $\left(111 \mathrm{mM} \mathrm{NaCl}, 4 \cdot 8 \mathrm{mM} \mathrm{KCl}, 2 \cdot 3 \mathrm{CaCl}_{2}\right.$, $1.2 \mathrm{mM} \mathrm{MgSO}_{4}, 1.2 \mathrm{mM} \mathrm{KH}_{2} \mathrm{PO}_{4}, 25 \mathrm{mM} \mathrm{NaHCO}_{3}$ pH 7.4), $10 \mathrm{mM}$ Hepes, $2 \cdot 8 \mathrm{mM}$ glucose, $0 \cdot 2 \%$ BSA fraction $\mathrm{V}$ (Sigma) and preincubated in the same buffer for $90 \mathrm{~min}$ at $37^{\circ} \mathrm{C}$ in humidified air $5 \% \mathrm{CO}_{2}$. Triplicate batches of five islets were transferred to borosilicate tubes containing $1 \mathrm{ml}$ of KRB supplemented with either $2.8 \mathrm{mM}$ glucose, $20 \mathrm{mM}$ glucose or $20 \mathrm{mM}$ glucose plus $275 \mu \mathrm{M}$ tolbutamide and incubated for $60 \mathrm{~min}$ at $37^{\circ} \mathrm{C}$. The medium was collected after gentle centrifugation and stored at $-20{ }^{\circ} \mathrm{C}$ for measurement of insulin.

\section{Measurement of advanced glycation end products}

The AGE-associated fluorescence (Ex 370 nm, Em $440 \mathrm{~nm}$ ) was estimated in media samples following enzymatic hydrolysis with proteinase $\mathrm{K}(10 \mu \mathrm{g} / \mathrm{ml})$. Samples were then analyzed using an on-line spectrofluorometric detection flow system as previously described by our group (Forbes et al. 2002). Results were expressed in arbitrary units (AU) corrected for the protein/peptide content of each sample estimated by an on-line absorbance detector (A 280).

\section{Islet insulin content}

Islets were lysed in ice cold acid-ethanol $(2 \% \mathrm{HCl}$ in $95 \%$ ethanol) and placed at $-20{ }^{\circ} \mathrm{C}$ for at least $1 \mathrm{~h}$. The samples were thawed and sonicated on ice for about 
20 min to complete the lysis. The supernatants were collected after gentle centrifugation $(900 \boldsymbol{g}$ for $5 \mathrm{~min}$ at $4{ }^{\circ} \mathrm{C}$ ) and kept at $-70{ }^{\circ} \mathrm{C}$ until measurement of insulin content by radioimmunoassay.

\section{Real-time quantitative RT-PCR}

Gene expression of mouse pro-insulin II in isolated pancreatic islets was determined using real-time quantitative RT-PGR performed using the TaqMan system (ABI Prism 7700, Perkin-Elmer Inc, PE Biosystems, Foster City, CA, USA), as previously described (Tikellis et al. 2003, 2004). Total RNA was extracted from freshly isolated pancreatic islets following homogenisation using the Ultra-Turrax (Janke \& Kunkel IKA, Labortechnik, Germany) in TRIZOL (Life Technologies Inc, Gaithersburg, MD, USA). cDNA was then synthesized with a reverse transcriptase reaction carried out using standard techniques (Superscript First Strand Synthesis System for RT-PCR, Life Technologies Inc) with random hexamers, dNTPs and total RNA. To assess genomic DNA contamination, controls without reverse transcriptase were included. The oligonucleotides and probe for mouse pro-insulin II were designed using the software program, 'Primer Express' (PE Applied Biosystems, Foster City, CA, USA) and are 3' oligonucleotide (5'-TCAAGCAGCACCTTTGTG GTT), 5' oligonucleotide (5'-GGGACATGGGTGTGT AGAAGAAG) and probe (FAM5'-CGCACACACCAG GTAG-MGB).

The RT-PCR multiplex reaction took place with $500 \mathrm{nmol} / \mathrm{l}$ of forward and reverse primer and $50 \mathrm{nmol} / \mathrm{l}$ of FAM/MGB probe and VIC/TAMRA 18S ribosomal probe, in Taqman universal PCR master mix (PE Biosystems, Foster City, CA, USA). Amplification of $18 \mathrm{~S}$ was used to correct for loading. Each sample was run and analyzed in triplicate.

\section{Measurement of glucose phosphorylating activity}

Approximately 300 islets were washed with $2 \cdot 8 \mathrm{mM}$ KRB twice and incubated for another $90 \mathrm{~min}$. Islets were homogenized in ice-cold buffer containing $20 \mathrm{mM}$ $\mathrm{K}_{2} \mathrm{HPO}_{4}, 1 \mathrm{mM}$ EDTA, $5 \mathrm{mM}$ dithiothreitol and $110 \mathrm{mM}$ KCl. The islet homogenate was then centrifuged at $12000 \boldsymbol{g}$ for $10 \mathrm{~min}$. The supernatant was used for glucokinase and hexokinase determination by a spectrophotometric assay (Andrikopoulos et al. 1993, Kooptiwut et al. 2002). The reaction volume contained $100 \mu \mathrm{l}$ of islet supernatant in $500 \mu \mathrm{l}$ of $50 \mathrm{mM}$ Hepes/HCl, pH 7.6, $100 \mathrm{mM} \mathrm{KCl,} \mathrm{7.4} \mathrm{mM} \mathrm{MgCl}_{2}$, $15 \mathrm{mM} \beta$-mercaptoethanol, $0.50 \mathrm{mM} \mathrm{NAD}{ }^{+}, 0.05 \%$ bovine serum albumin, $0 \cdot 70 \mathrm{unit} / \mathrm{ml}$ glucose-6phosphate dehydrogenase from Leuconostoc mesenterodes and $5 \mathrm{mM}$ ATP. The reaction was performed for $90 \mathrm{~min}$ and absorbance measured at $340 \mathrm{~nm}$. The activity of glucokinase was calculated by subtracting the activity of hexokinase, which was determined at a glucose concentration of $0.5 \mathrm{mM}$ from the total phosphorylating activity, measured at $100 \mathrm{mM}$ glucose.

\section{Glucokinase, hexokinase and GLUT2 Western blot analysis}

Western blot analyses were performed as previously described (Kooptiwut et al. 2002) to quantify glucokinase, hexokinase and GLUT2 protein levels. Following incubation, approximately 400-500 islets were sonicated for $20 \mathrm{~min}$ at $4{ }^{\circ} \mathrm{C}$ in a lysis buffer containing $5 \%$ SDS, $80 \mathrm{mM}$ Tris / HGl, pH 6.8, $5 \mathrm{mM}$ EDTA, $1 \mathrm{mM}$ phenylmethylsulfonylfluoride, $10 \mu \mathrm{g}$ DNase I, and $0.2 \mathrm{mM}$ N-ethylmaleimide. The lysate was retrieved after centrifugation at $12000 \mathrm{~g}$ for $10 \mathrm{~min}$ at $4{ }^{\circ} \mathrm{C}$. Protein content was measured by the Bio-Rad protein assay kit (Bio-Rad, Hercules, CA, USA). Samples containing $20 \mu \mathrm{g}$ of protein were resolved by electrophoresis through a $10 \%$ (for glucokinase and GLUT2) or $7 \cdot 5 \%$ (for hexokinase) polyacrylamide gel. Following transfer to PVDF membrane glucokinase was immunodetected using a specific anti-glucokinase antibody (cat \# sc-7908, Santa Cruz Biotech. Inc, Santa Cruz, CA, USA) at a 1:500 dilution followed by incubation with swine anti-rabbit IgG at 1:2500 dilution. Hexokinase was immunodetected using a specific anti-hexokinase antibody (cat \# sc-6517, Santa Cruz Biotech. Inc) at a 1:500 dilution followed by incubation with swine anti-goat IgG at 1:2500 dilution. GLUT2 was immunodetected using a specific anti-GLUT2 antibody (cat \# sc-9117, Santa Cruz Biotech. Inc) at a 1:2000 dilution followed by incubation with swine anti-rabbit IgG at 1:2500 dilution. Protein bands were visualized by enhanced chemiluminescence (Renaissance, NEN Life Science Products Inc, Boston MA, USA) and quantified using scanning densitometry.

\section{Cell viability assay}

Viable cell ratios were determined at each time-point using the dye exclusion assay (Altman et al. 1993). This assay is based on the exclusion of trypan blue dye from viable cells. Ten islets were picked and treated with trypsin/EDTA for $15-20 \mathrm{~min}$ at $37^{\circ} \mathrm{C}$. The cell suspension was then centrifuged at $900 \boldsymbol{g}$ for $10 \mathrm{~min}$ at $4{ }^{\circ} \mathrm{C}$ and the pellet resuspended in Hanks' Balanced Salt Solution (HBSS). Cells were then incubated with trypan blue (final concentration, $0 \cdot 2 \mathrm{mg} / \mathrm{ml}$ ) for 3-5 min and observed under a microscope. Viable (unstained) and non-viable (stained) cells were counted with a hemocytometer and the viable cell ratio calculated. 


\section{Statistical Analysis}

Insulin secretion results were corrected for and expressed as the percent of total islet insulin content. Data is presented as mean \pm S.E.M. for the number indicated. Statistical analysis was performed using the Mann-Whitney $U$ test and the Wilcoxon paired test. A $P<0 \cdot 05$ was considered significant.

\section{Results}

\section{Islet culture in $11.1 \mathrm{mM}$ or $40 \mathrm{mM}$ glucose for 10 days}

Isolated DBA/2 and C57BL/6 mouse islets were cultured in $11.1 \mathrm{mM}$ glucose for 10 days, insulin release was assessed at basal $(2 \cdot 8 \mathrm{mM})$ and stimulating $(20 \mathrm{mM})$ glucose concentrations. Fig. 1A shows that insulin release was stimulated with $20 \mathrm{mM}$ glucose from both DBA/2 and C57BL/6 mouse islets. As we have previously shown (Kooptiwut et al. 2002) insulin release was increased from DBA/2 compared with C57BL/6 islets at both $2.8 \mathrm{mM}$ and $20 \mathrm{mM}$ glucose.

Incubation of the islets with $40 \mathrm{mM}$ glucose for 10 days increased basal insulin release in both DBA/2 $(35.2 \pm 5.8$ vs $1.2 \pm 0 \cdot 2 \%$ content, $\quad P<0.05)$ and C57BL/ $6(17 \cdot 9 \pm 6 \cdot 0$ vs $0 \cdot 3 \pm 0 \cdot 1 \%$ content, $P<0 \cdot 05)$ mice but the increase was more marked in DBA/2 compared with $\mathrm{C} 57 \mathrm{BL} / 6$ islets $(P<0 \cdot 05)$. When stimulated with $20 \mathrm{mM}$ glucose insulin secretion was significantly increased from $\mathrm{C} 57 \mathrm{BL} / 6$ islets while there was no change from DBA/2 islets when compared with $2.8 \mathrm{mM}$ glucose condition (Fig. 1A). However, when challenged with $20 \mathrm{mM}$ glucose $+275 \mu \mathrm{M}$ tolbutamide, there was a significant increase in insulin release from DBA/2 islets $(P<0 \cdot 05)$. This suggests a functional defect in DBA/2 islets when chronically incubated with $40 \mathrm{mM}$ glucose.

To determine the effects of advanced glycation end products on secretory function, aminoguanidine was added to $\mathrm{DBA} / 2$ and $\mathrm{C} 57 \mathrm{BL} / 6$ islets cultured for 10 days in $40 \mathrm{mM}$ glucose. Incubation of islets in the presence of $1 \mathrm{mM}$ aminoguanidine significantly reduced basal insulin secretion from DBA/2 $(35 \cdot 2 \pm 5 \cdot 8$ vs $5 \cdot 9 \pm 1 \cdot 0 \%$ content, $P<0 \cdot 05)$ and C57BL/6 $(17 \cdot 9 \pm 6 \cdot 0$ vs $2 \cdot 5 \pm 0 \cdot 5 \%$ content, $P<0 \cdot 05)$ mouse islets (Fig. $1 \mathrm{~A}$ ). Furthermore, insulin release in response to $20 \mathrm{mM}$ glucose was significantly higher from both $\mathrm{DBA} / 2$ and C57BL/6 islets compared with the respective $2 \cdot 8 \mathrm{mM}$ glucose condition. This suggests that aminoguanidine improves insulin secretory function in DBA/2 mouse islets.

When the insulin secretion was expressed as a fold above basal $(2.8 \mathrm{mM}$ glucose), the stimulation in response to glucose was similar between the two strains of mice when cultured at $11 \cdot 1 \mathrm{mM}$ glucose for 10 days
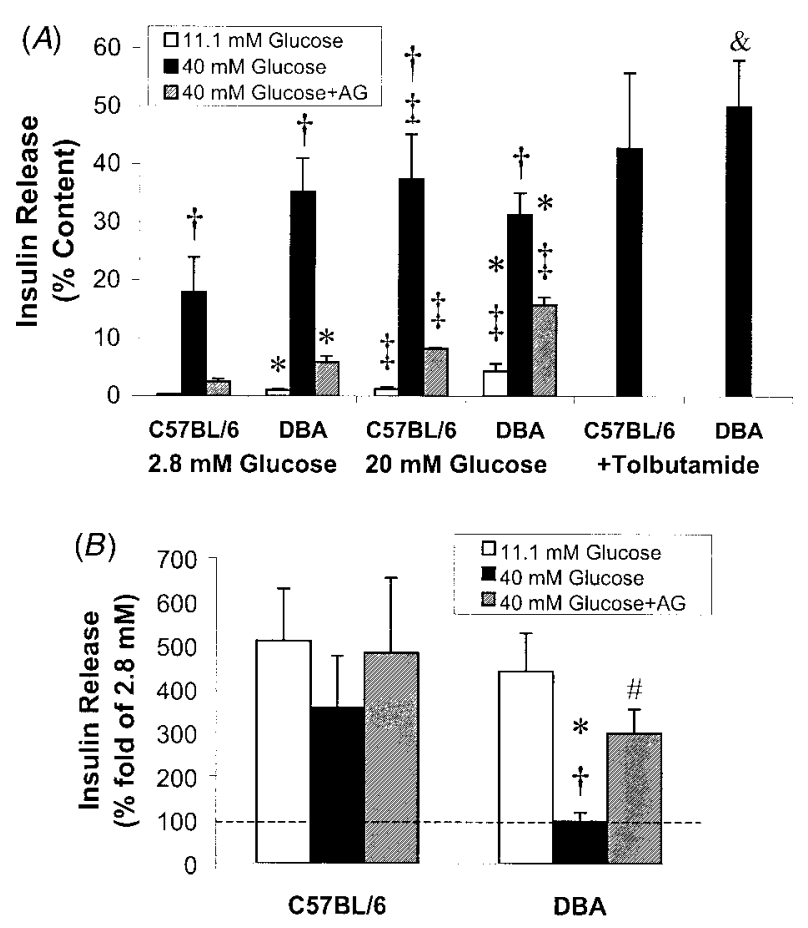

$20 \mathrm{mM}$ Glucose

Figure 1 (A) Glucose-mediated insulin secretion in islets incubated with $11.1 \mathrm{mM}$ glucose or $40 \mathrm{mM}$ glucose in the absence or presence of $1 \mathrm{mM}$ aminoguanidine (AG) for 10 days. Islets from 8-10 week-old DBA/2 and C57BL/6 mice were isolated as described in the Materials and methods section and batches of five islets preincubated in KREBS buffer containing $2.8 \mathrm{mM}$ glucose for 90 minutes. Insulin secretion was assessed at $2.8 \mathrm{mM}$ glucose, $20 \mathrm{mM}$ glucose or $20 \mathrm{mM}$ glucose $+275 \mu \mathrm{M}$ tolbutamide over a $60 \mathrm{~min}$ period. (B) Insulin secretion expressed as fold increase of the result obtained with $2.8 \mathrm{mM}$ glucose. Results are presented as means \pm S.E.M. $(n=6)$. ${ }^{*} P<0.05$ compared with C57BL/6 mouse islets, $\# P<0.05$ compared with islets incubated with $1 \mathrm{mM}$ aminoguanidine, $\dagger P<0.05$ compared with islets incubated in $11.1 \mathrm{mM}$ glucose for 10 days, $\ddagger P<0.05$ compared with islets stimulated with $2.8 \mathrm{mM}$ glucose for 60 minutes, \& $P<0.05$ compared with islets stimulated with $20 \mathrm{mM}$ glucose for 60 minutes.

(Fig. 1B) indicative of comparable islet function. In contrast, following culture at $40 \mathrm{mM}$ glucose for 10 days, despite an increase in basal insulin secretion in both strains, fold stimulation of insulin secretion was completely blocked in DBA/2 mouse islets compared with $11.1 \mathrm{mM}$ glucose for 10 days but not in C57BL/6 islets, illustrating the susceptibility of DBA/2 mouse islets to a high glucose milieu. Aminoguanidine significantly increased fold-induced insulin release in high glucose cultured DBA/2 mouse islets, but had no effect in fold stimulation of insulin release from C57BL/6 mouse islets cultured in $40 \mathrm{mM}$ glucose.

Culture in $40 \mathrm{mM}$ glucose for 10 days caused a comparable increase in AGE in both $\mathrm{DBA} / 2$ and 


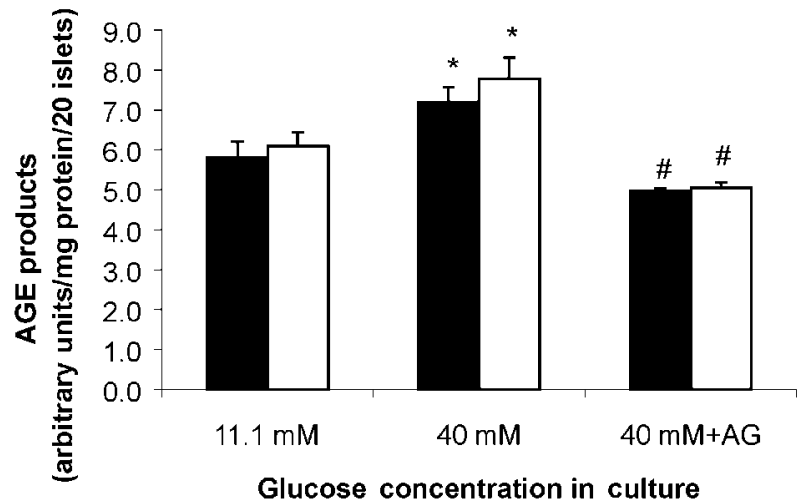

Figure 2 Advanced glycation end products (AGE) (Ex $370 \mathrm{~nm}$, $\mathrm{Em} 440 \mathrm{~nm}$, normalized to protein content at $280 \mathrm{~nm}$ ) in DBA/2 (open bars) and C57BL/6 (solid bars) islets incubated in $11.1 \mathrm{mM}$ glucose or $40 \mathrm{mM}$ glucose in the absence or presence of $1 \mathrm{mM}$ aminoguanidine (AG) for 10 days. Results are presented as means \pm S.E.M. $(n=3) .{ }^{*} P<0.05$ compared with islets incubated in $11.1 \mathrm{mM}$ glucose, $\# P<0.05$ compared with islets incubated in $40 \mathrm{mM}$ glucose.

C57BL/6 islets (Fig. 2). Aminoguanidine resulted in a reduction in AGE in both strains of mice.

\section{Islet insulin content and mRNA}

Insulin content and mRNA levels in islets cultured with $11 \cdot 1 \mathrm{mM}$ or $40 \mathrm{mM}$ glucose for 10 days is shown in Fig. 3. There was a marked decrease in islet insulin content following $40 \mathrm{mM}$ glucose compared with $11 \cdot 1 \mathrm{mM}$ glucose culture in both strains of mice, with no difference in insulin content between DBA/2 and C57BL/6 islets (Fig. 3A). Treatment with aminoguanidine resulted in increased insulin content in islets from both strains of mice incubated with $40 \mathrm{mM}$ glucose for 10 days (Fig. 3A). However, DBA/2 mouse islets contained significantly less insulin following $40 \mathrm{mM}$ glucose plus aminoguanidine treatment compared with similarly treated C57BL/6 mouse islets.

In contrast insulin mRNA was significantly increased in both DBA/2 and C57BL/6 islets following incubation in $40 \mathrm{mM}$ glucose for 10 days (Fig. 3B). Aminoguanidine had no effect on insulin mRNA in either strain compared with $40 \mathrm{mM}$ glucose incubation for 10 days. There was a trend $(P=0 \cdot 1)$ for insulin mRNA to be higher in DBA/2 compared with $\mathrm{C} 57 \mathrm{BL} / 6$ islets incubated with $11 \cdot 1 \mathrm{mM}$ glucose for 10 days (Fig. 3B).

\section{Cell viability}

Cell viability was determined under the culture conditions described above and the data shown in Fig. 4. Chronic high glucose culture resulted in decreased cell viability in both strains, being statistically significant at 6 ,

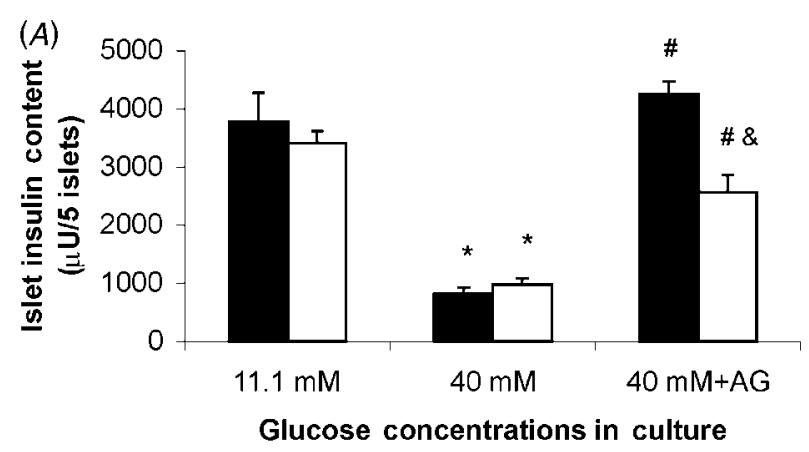

(B)

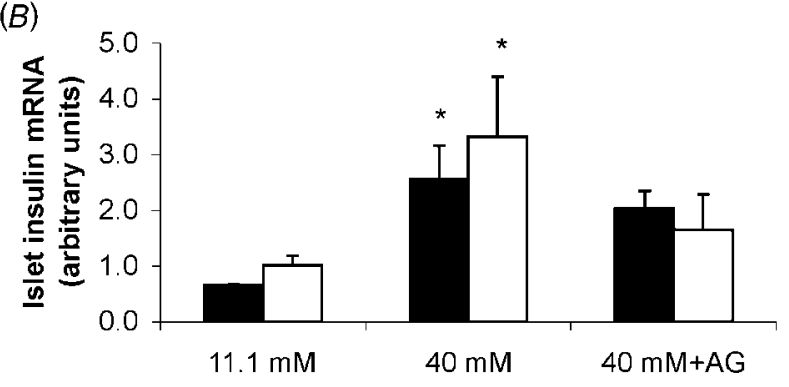

Glucose concentration in culture

Figure 3 (A) Insulin content in DBA/2 (solid bars) and C57BL/6 (open bars) islets incubated in $11.1 \mathrm{mM}$ glucose or $40 \mathrm{mM}$ glucose in the absence or presence of $1 \mathrm{mM}$ aminoguanidine (AG) for 10 days. Results are presented as means \pm S.E.M. $(n=6)$. (B) Insulin mRNA in DBA/2 (solid bars) and C57BL/6 (open bars) islets incubated in $11.1 \mathrm{mM}$ glucose or $40 \mathrm{mM}$ glucose in the absence or presence of $1 \mathrm{mM} \mathrm{AG}$ for 10 days. Results are presented as means \pm S.E.M. $(n=3) .{ }^{*} P<0.05$ compared with islets incubated in $11.1 \mathrm{mM}$ glucose, $\# P<0.05$ compared with islets incubated in $40 \mathrm{mM}$ glucose, \& $P<0.05$ compared with similarly treated $\mathrm{C} 57 \mathrm{BL} / 6$ islets.

8 and 10 days for C57BL/6 (Fig. 4A) and at 8 and 10 days for DBA/2 (Fig. 4B) mouse islets. At 10 days, cell viability was the same between $\mathrm{C} 57 \mathrm{BL} / 6$ and $\mathrm{DBA} / 2$ mice $(72 \cdot 6 \pm 1 \cdot 0 \%$ vs $74 \cdot 0 \pm 1 \cdot 8 \%, P=0 \cdot 52)$. Aminoguanidine treatment completely reversed the decrease in cell viability caused by high glucose in both strains of mice (Figs $4 \mathrm{~A}$ and $\mathrm{B}$ ).

\section{Islet glucokinase, hexokinase and GLUT2 Levels}

A possible mechanism was investigated for the changes in insulin secretion in DBA/2 mouse islets incubated with $40 \mathrm{mM}$ glucose in the presence of comparable insulin content and cell viability between the two strains of mice. To determine whether the altered insulin secretion in DBA/2 islets following chronic high glucose was the result of impaired glucose sensing, the protein levels of glucokinase, hexokinase and GLUT2 were measured and the results shown in Fig. 5. Western blotting on freshly isolated islets showed that glucokinase 

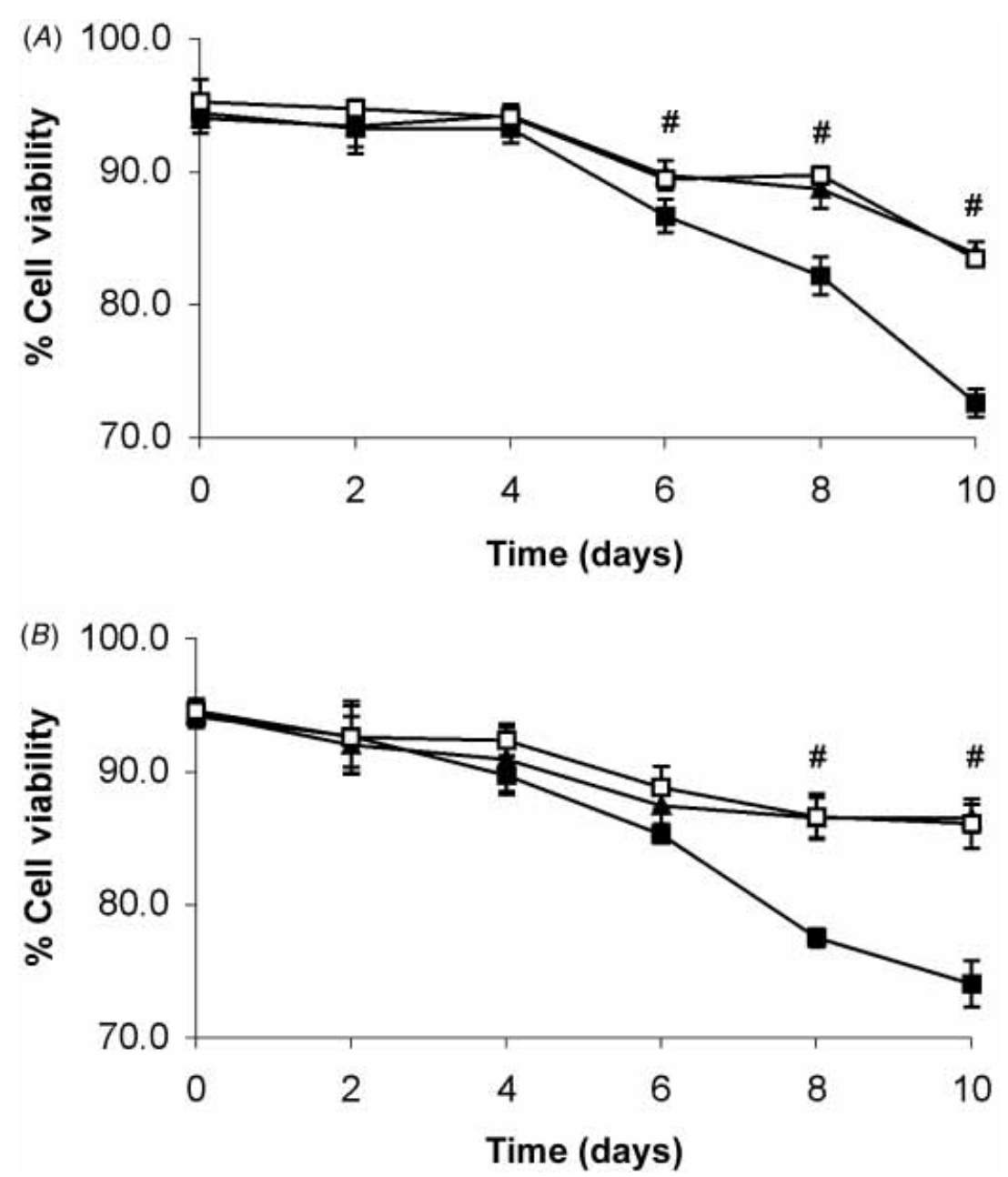

Figure 4 Cell viability determinations in C57BL/6 (A) and DBA/2 (B) islets incubated in $11.1 \mathrm{mM}$ glucose $(\boldsymbol{\Delta})$ or $40 \mathrm{mM}$ glucose in the absence $(\square)$ or presence $(\square)$ of $1 \mathrm{mM}$ aminoguanidine for 10 days. Results are presented as means \pm S.E.M. $(n=3)$. \# $P<0.05$ compared with islets incubated in $40 \mathrm{mM}$ glucose.

levels were comparable between the two strains of mice $(18.9 \pm 0 \cdot 6$ vs $20 \cdot 0 \pm 1 \cdot 3$ arbitrary units $\mathrm{C} 57 \mathrm{BL} / 6$ vs $\mathrm{DBA} / 2, n=3, P=0 \cdot 5)$. Glucokinase protein levels were also similar between $\mathrm{DBA} / 2$ and $\mathrm{C} 57 \mathrm{BL} / 6$ islets following $11 \cdot 1 \mathrm{mM}$ glucose culture for 10 days. Culture with $40 \mathrm{mM}$ glucose for 10 days resulted in reduced glucokinase in DBA/2 but not C57BL/6 islets. Furthermore, glucokinase protein levels were also $50 \%$ lower in DBA/2 mouse islets than that detected in C57BL/6 mouse islets (Fig. 5). In addition glucokinase activity was also decreased in DBA/2 compared with C57BL/ 6 islets following high glucose culture $(2 \cdot 6 \pm 0 \cdot 5$ vs $3 \cdot 8 \pm 0.5 \mathrm{nmol} / \mathrm{min} / \mathrm{mg}$ protein, $n=6, \quad P=0 \cdot 05)$. Aminoguanidine treatment resulted in significantly increased glucokinase protein levels in DBA/2 mouse islets incubated with $40 \mathrm{mM}$ glucose for 10 days (Fig. 5). In contrast, the presence of this drug did not affect glucokinase protein levels in C57BL/6 mouse islets incubated with $40 \mathrm{mM}$ glucose for 10 days (Fig. 5).

To determine the effect of chronic high glucose on the protein levels of other components of the glucose sensing system, GLUT2 and hexokinase levels were measured and the results shown in Fig. 6. There was no difference in GLUT2 protein levels between the two strains of mice (Fig. 6A). The lack of change in hexokinase activity $(3 \cdot 1 \pm 0 \cdot 3$ vs $3 \cdot 2 \pm 0 \cdot 9 \mathrm{nmol} / \mathrm{min} / \mathrm{mg}$ protein, $n=6$, $P=0 \cdot 4)$ was also reflected in no change in hexokinase protein levels (Fig. 6B).

\section{Discussion}

Glucokinase is the $\beta$-cell glucose-sensor for insulin secretion (Steiner \& James 1992, Matschinsky 1996, 

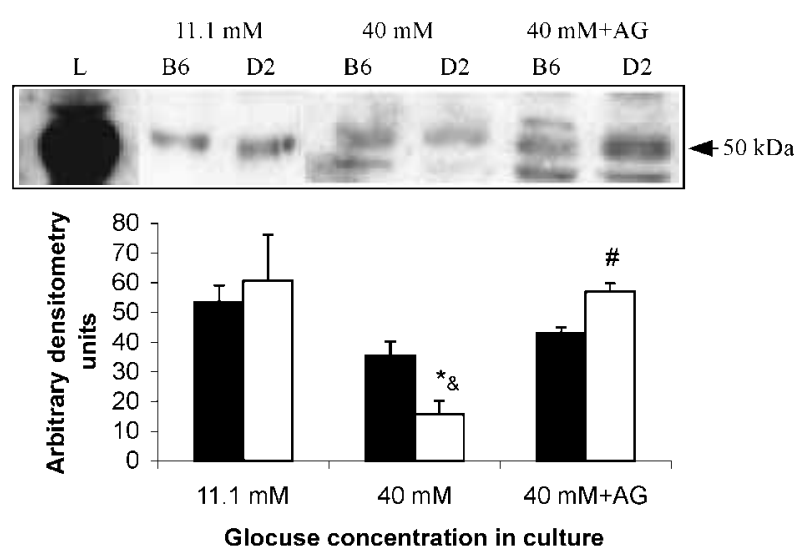

Figure 5 Glucokinase protein levels in DBA/2 (D2, open bars) and C57BL/6 (B6, solid bars) mouse islets incubated with $11.1 \mathrm{mM}$ glucose or $40 \mathrm{mM}$ glucose for 10 days in the absence or presence of $1 \mathrm{mM}$ aminoguanidine (AG). A liver lysate (L) was used as an internal control. The graph is the means \pm S.E.M of at least three independent experiments. ${ }^{*} P<0.05$ compared with islets incubated in $11.1 \mathrm{mM}$ glucose, $\# P<0.05$ compared with islets incubated in $40 \mathrm{mM}$ glucose, \& $P<0.05$ compared with similarly treated C57BL/6 islets.

Schuit et al. 2001). Deletion of one allele of $\beta$-cell glucokinase by homologous recombination in mice resulted in reduced glucose-mediated insulin release (Terauchi et al. 1995, Andrikopoulos et al. 2000). Interestingly while stimulated insulin levels were lower in the heterozygous knockout mice, basal insulin levels were not different to wildtype and were trending towards being higher (Terauchi et al. 1995, Andrikopoulos et al. 2000). In the present study we showed that chronic high glucose incubation caused a $50 \%$ decrease in glucokinase protein levels and this was associated with a reduction in glucose-stimulated insulin release from DBA/2 islets. This is in contrast to a previous study which showed an increase in glucokinase activity levels following high glucose culture (Liang et al. 1994). The reason for the discrepancy could be due to a difference in strain backgrounds (a hybrid background vs DBA/2 in our study) and the length of time and concentration of glucose $(30 \mathrm{mM}$ for 4 days vs $40 \mathrm{mM}$ glucose for 10 days in our study). While chronic $40 \mathrm{mM}$ glucose incubation resulted in increased basal insulin secretion, this occurred in both strains of mice. Furthermore tolbutamide was able to elicit a significant increase in insulin release from DBA/2 islets incubated chronically with $40 \mathrm{mM}$ glucose. Thus while the increase in basal insulin secretion may have been a contributory factor, we believe that the reduction in islet glucokinase was the main cause of the reduction in function of DBA/2 islets. Increases in basal insulin secretion following high glucose culture have previously been shown in rat islets and purified $\beta$-cells (Purrello et al. 1989, Ling et al. 1996, Tajiri et al. 1997). Furthermore, we showed that
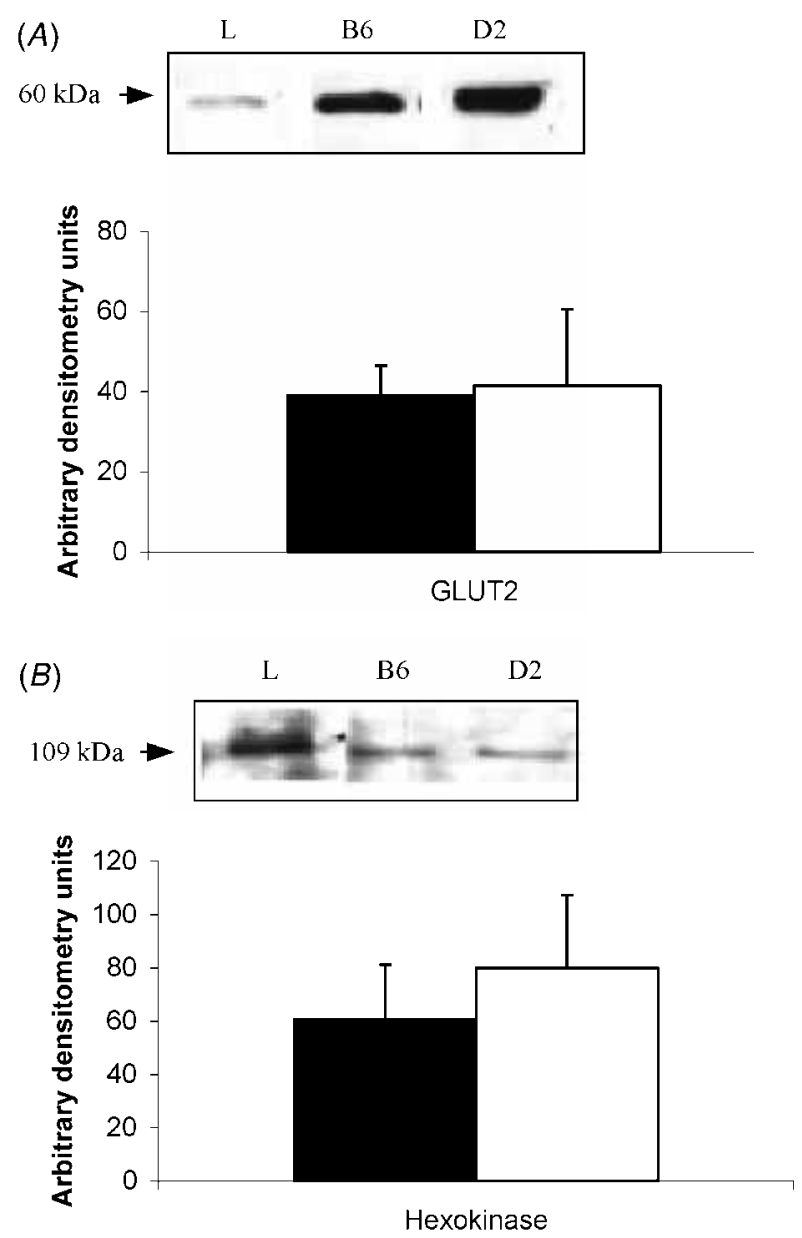

Figure 6 (A) Hexokinase and (B) GLUT2 protein levels in $\mathrm{DBA} / 2$ (D2, open bars) and C57BL/6 (B6, solid bars) mouse islets incubated with $40 \mathrm{mM}$ glucose for 10 days in the absence or presence of $1 \mathrm{mM}$ aminoguanidine. A liver lysate (L) was used as an internal control. The graph is the mean \pm S.E.M. of six independent experiments.

aminoguanidine, an inhibitor of the glycation process reduced basal insulin secretion in both $\mathrm{DBA} / 2$ and C57BL/6 islets following high glucose culture, but was associated with significant increases in glucokinase levels only in the DBA/2 mouse. This further supports the notion that the effect of high glucose to reduce glucose-mediated insulin secretion from the DBA/2 islet is associated with reduced glucokinase levels.

Formation of advanced glycation end products has been shown to be detrimental to islet function, an effect improved by aminoguanidine (Tajiri et al. 1997). This is corroborated by a study in the immortal $\beta$-cell line HIT-T15 in which induction of glycation suppressed the activity of the glucokinase promoter resulting in reduced mRNA and protein levels (Kajimoto et al. 1999). Furthermore it was shown that the inhibition of glucokinase gene expression was prevented by treatment 
with $\mathrm{N}$-acetyl-cysteine or aminoguanidine providing further evidence that increased glycation was involved (Kajimoto et al. 1999). While it has been suggested that aminoguanidine may act by inhibiting nitric oxide synthase, evidence suggests that in pancreatic islets the main mechanism of action is via reduction of AGE (Tajiri et al. 1997). This study demonstrated that $\mathrm{N}^{\mathrm{G}}$-Methyl-L-arginine, a nitric oxide synthase inhibitor, failed to reproduce the beneficial effects of aminoguanidine in rat islets. It has also been shown that the effects of aminoguanidine on insulin secretion are not via inhibition of glucose oxidation (Eizirik et al. 1994). One may also argue that aminoguanidine itself is directly increasing glucokinase levels and thus its effect is independent of glycation inhibition. However, we did not see a similar increase in glucokinase protein levels in control C57BL/6 islets treated with aminoguanidine. It is of interest that the increase in AGE with high glucose culture was similar in DBA/2 and C57BL/6 islets, yet only the former displayed a defect in insulin secretion, associated with reduced glucokinase levels. Furthermore the fact that these phenotypic differences between the two strains were present in vitro 10 days after removal from the in vivo situation indicates that they are due to genetic variations. This suggests that $\mathrm{DBA} / 2$ mice are not able to cope with oxidative stress as well as C57BL/6 mice and this may be due to the inherent susceptibility of DBA/2 islets to develop diabetes when exposed to a permissive environment (Leiter et al. 1981, Leiter 1987, Pehuet-Figoni et al. 1994).

Other explanations have been proposed for high glucose induced impairments in insulin release. Chronic high glucose incubation has been shown to cause excessive insulin secretion depleting intracellular stores (Sako \& Grill 1990, Kaiser et al. 1991, Eizirik et al. 1992, Ling et al. 1996, Bjorklund et al. 2000), this effect being prevented by agents, such as diazoxide (Sako \& Grill 1990, Bjorklund et al. 2000), that inhibit insulin release. It has also been suggested that chronic high glucose resulted in reduced insulin biosynthesis as a result of decreased expression of the insulin gene transcription factors PDX-1 and RIPE-3bl (Robertson et al. 1992, Poitout et al. 1996, Moran et al. 1997, Marshak et al. 1999). Consequently increased D-ribose induced glycation has been shown to cause a decrease in insulin gene promoter activity, which was prevented by aminoguanidine (Matsuoka et al. 1997). Moreover, aminoguanidine has been shown to cause an increase in proinsulin biosynthesis while decreasing AGE-related fluorescence in rat islets chronically incubated with $38 \mathrm{mM}$ glucose (Tajiri et al. 1997). Lastly, aminoguanidine and other antioxidants have been shown to increase $\beta$-cell mass in diabetic C57BL/KsJ- $d b / d b$ mice (Kaneto et al. 1999, Piercy et al. 1998).

In our study we found that incubation with $40 \mathrm{mM}$ glucose caused reduced insulin content and cell viability in both DBA/2 and C57BL/6 islets. Aminoguanidine treatment caused a significant increase in islet insulin content and cell viability in cells incubated with $40 \mathrm{mM}$ glucose in both DBA/2 and C57BL/6 islets. The failure to find a difference in cell survival between the DBA/2 and C57BL/6 islets was surprising given the existing data showing a marked difference in survival of these islets when exposed in vivo to hyperglycemia (Baetens et al. 1978, Leiter et al. 1981, Molina et al. 1984). The difference could be due to the duration of the exposure to hyperglycemia or to the presence of other factors contributing to cell death in the DBA/2 mice that are present in vivo but not in vitro. It is likely that a separate mechanism operates in DBA/2 mice exposed to hyperglycemia for longer. However it appears that aminoguanidine can also block this mechanism since it has been shown that this agent prevents $\beta$-cell death when administered in vivo to $\mathrm{C} 57 \mathrm{BL} / \mathrm{KsJ}-d b / d b$ mice (Kaneto et al. 1999, Piercy et al. 1998).

Interestingly we found that islet insulin mRNA was in fact increased following $40 \mathrm{mM}$ glucose culture for 10 days and that aminoguanidine had no further effect in both strains of mice. Thus, the increase in insulin content that we observe in both the $\mathrm{DBA} / 2$ and C57BL/6 islets following aminoguanidine treatment is most probably due to a decrease in chronic secretion or an increase in cell viability or more likely a combination of both of these processes. However, since there was no difference in islet insulin content, insulin mRNA and cell viability between the two strains of mice regardless of culture condition, these cannot explain the changes in insulin release in the DBA/2 mouse following $40 \mathrm{mM}$ glucose exposure for 10 days. This provides further support for our finding that reduction of glucokinase levels may be responsible for the impairment of secretory function following chronic high glucose exposure of $\mathrm{DBA} / 2$ but not $\mathrm{C} 57 \mathrm{BL} / 6$ islets.

In conclusion, we show that islets from susceptible DBA/2 mice display increased basal insulin secretion and decreased glucose-stimulated secretory function when chronically incubated in high glucose associated with a decrease in glucokinase but not hexokinase levels. Furthermore, treatment with aminoguanidine, which is an inhibitor of the glycation process, was able to reduce basal insulin secretion, increase glucokinase protein levels and prevent this reduction in function in DBA/2 islets. Thus, in our study we demonstrate that hyperglycemia has multiple effects on islets, such as cell viability, reduced insulin content, increased insulin mRNA, which do not vary between mouse strains, yet these strains differ in their susceptibility to $\beta$-cell failure. In contrast, islets from a mouse with increased $\beta$-cell failure susceptibility have abnormal regulation of glucokinase. How this occurs, or if this is related to subsequent $\beta$-cell failure is not clear and warrants further study. 


\section{Acknowledgements}

We would like to thank Sue Franchescini, Marisa Fielding, Naomi Kujala and Paul Brazzoduro for excellent technical assistance. This study was supported by grants from the Diabetes Australia Research Trust (to SA, MD and JP) and the National Health and Medical Research Council of Australia (\# 114163 to SA and JP). The authors declare that there is no conflict of interest that would prejudice the impartiality of this scientific work.

\section{References}

Altman SA, Randers L \& Rao G 1993 Comparison of trypan blue dye exclusion and fluorometric assays for mammalian cell viability determinations. Biotechnology Progress 9 671-674.

Andrikopoulos S, Rosella G, Gaskin E, Thorburn A, Kaczmarczyk S, Zajac JD \& Proietto J 1993 Impaired regulation of hepatic fructose-1,6-bisphosphatase in the New Zealand obese mouse model of NIDDM. Diabetes 42 1731-1736.

Andrikopoulos S, Verchere CB, Terauchi Y, Kadowaki T \& Kahn SE $2000 \beta$-cell glucokinase deficiency and hyperglycemia are associated with reduced islet amyloid deposition in a mouse model of type 2 diabetes. Diabetes 49 2056-2062.

Baetens D, Stefan Y, Ravazzola M, Malaisse-Lagae F, Coleman DL \& Orci L 1978 Alteration of islet cell populations in spontaneously diabetic mice. Diabetes 27 1-7.

Bedoya FJ \& Jeanrenaud B 1991 Evolution of insulin secretory response to glucose by perifused islets from lean (FA/FA) rats chronically infused with glucose. Diabetes 40 7-14.

Bjorklund A, Lansner A \& Grill VE 2000 Glucose-induced [Ca2+]i abnormalities in human pancreatic islets: important role of overstimulation. Diabetes 49 1840-1848.

Davalli AM, Ricordi C, Socci C, Braghi S, Bertuzzi F, Fattor B, Di Carlo V, Pontiroli AE \& Pozza G 1991 Abnormal sensitivity to glucose of human islets culture in a high glucose medium: partial reversibility afer an additional culture in a normal glucose medium. Fournal of Clinical Endocrinology and Metabolism 72 202-208.

Eizirik DL, Korbutt GS \& Hellerstrom C 1992 Prolonged exposure of human pancreatic islets to high glucose concentrations in vitro impairs the $\beta$-cell function. Fournal of Clinical Investigation $\mathbf{9 0}$ $1263-1268$.

Eizirik DL, Sandler S, Welsh N, Cetkovic-Cvrlje M, Nieman A, Geller DA, Pipeleers DG, Bendtzen K \& Hellerstrom C 1994 Cytokines suppress human islet function irrespective of their effects on nitric oxide generation. Fournal of Clinical Investigation 93 $1968-1974$

Forbes JM, Cooper ME, Thallas V, Burns WC, Thomas MC, Brammar GC, Lee F, Grant SL, Burrell LA, Jerums G \& Osicka TM 2002 Reduction of the accumulation of advanced glycation end products by ACE inhibition in experimental diabetic nephropathy. Diabetes $\mathbf{5 1} 3274-3282$.

Forbes JM, Cooper ME, Oldfield MD \& Thomas MC 2003 Role of advanced glycation end products in diabetic nephropathy. Fournal of the American Society of Nephrology 14 S254-S258.

Kaiser N, Corcos AP, Sarel I \& Cerasi E 1991 Monolayer culture of adult rat pancreatic islets on extracellular matrix: modulation of B-cell function by chronic exposure to high glucose. Endocrinology 129 2067-2076.

Kajimoto Y, Matsuoka T, Kaneto H, Watada H, Fujitani Y, Kishimoto M, Sakamoto K, Matsuhisa M, Kawamori R, Yamasaki Y \& Hori M 1999 Induction of glycation suppresses glucokinase gene expression in HIT-T15 cells. Diabetologia $\mathbf{4 2}$ $1417-1424$.

Kajimoto Y, Watada H, Matsuoka T, Kaneto H, Fujitani Y, Miyazaki J \& Yamasaki Y 1997 Suppression of transcription factor PDX-1/IPF-1/STF-1/IDX-1 causes no decrease in insulin mRNA in MIN6 cells. Fournal of Clinical Investigation $\mathbf{1 0 0}$ 1840-1846.

Kaneto H, Kajimoto Y, Miyagawa J, Matsuoka T, Fujitani Y, Umayahara T, Matsuzawa Y, Yamasaki Y \& Hori M 1999 Beneficial effects of antioxidants in diabetes. Possible protection of pancreatic $\beta$-cells against glucose toxicity. Diabetes $\mathbf{4 8}$ 2398-2406.

Kooptiwut S, Zraika S, Thorburn AW, Dunlop ME, Darwiche R, Kay TW, Proietto J \& Andrikopoulos S 2002 Comparison of insulin secretory function in two mouse models with different susceptibility to beta-cell failure. Endocrinology 143 2085-2092.

Leahy JL, Cooper HE \& Weir GG 1987 Impaired insulin secretion associated with near normoglycemia. Diabetes 36 459-464.

Leiter EH 1987 Analysis of differential survival of syngeneic islets transplanted into hyperglycemic C57BL/6J versus $\mathrm{C} 57 \mathrm{BL} / \mathrm{KsJ}$ mice. Transplantation 44 401-406.

Leiter EH, Coleman DL \& Hummel KP 1981 The influence of genetic background on the expression of mutations at the diabetes locus in the mouse. III. Effect of H-2 haplotype and sex. Diabetes 30 1029-1034.

Liang Y, Jetton TL, Zimmerman EG, Najafi H, Berner DK, Matschinsky FM \& Magnuson MA 1994 Effects of glucose on insulin secretion, glucokinase activity, and transgene expression in transgenic mouse islets containing an upstream glucokinase promoter - human growth hormone fusion gene. Diabetes $\mathbf{4 3}$ $1138-1145$.

Ling Z, Kiekens R, Mahler T, Schuit FC, Pipeleers-Marichal M, Sener A, Kloppel G, Malaisse WJ \& Pipeleers DG 1996 Effects of chronically elevated glucose levels on the functional properties of rat pancreatic $\beta$-cells. Diabetes 45 1774-1782.

Marshak S, Leibowitz G, Bertuzzi F, Socci C, Kaiser N, Gross DJ, Cerasi E \& Melloul D 1999 Impaired $\beta$-cell functions induced by chronic exposure of cultured human pancreatic islets to high glucose. Diabetes 48 1230-1236.

Matschinsky FM 1996 Banting Lecture 1995. A lesson in metabolic regulation inspired by the glucokinase glucose sensor paradigm. Diabetes 45 223-241.

Matsuoka T, Kajimoto Y, Watada H, Kaneto H, Kishimoto M, Umayahara Y, Fujitani Y, Kamada T, Kawamori R \& Yamasaki Y 1997 Glycation-dependent, reactive oxygen species-mediated suppression of the insulin gene promoter activity in HIT cells. Fournal of Clinical Investigation 99 144-150.

Molina JM, Premdas FH, Klenck RE, Eddlestone G, Oldham SB \& Lipson LG 1984 The dynamic insulin secretory response of isolated pancreatic islets of the diabetic mouse. Evidence for a gene dosage effect on insulin secretion. Diabetes 33 1120-1123.

Moran A, Zhang HJ, Olson K, Harmon JS, Poitout V \& Robertson RP 1997 Differentiation of glucose toxicity from beta cell exhaustion during the evolution of defective insulin gene expression in the pancreatic islet cell line, HIT-T15. Fournal of Clinical Investigation 99 534-539.

Naggert JK, Mu JL, Frankel W, Bailey DW \& Paigen B 1995 Genomic analysis of the C57BL/Ks mouse strain. Mammalian Genome 6 131-133.

Pehuet-Figoni M, Ballot E, Bach JF \& Chatenoud L 1994 Aberrant function and long-term survival of mouse $\beta$ cells exposed in vitro to high glucose concentrations. Cell Transplant 3 445-451.

Piercy V, Toseland CD \& Turner NC 1998 Potential benefit of inhibitors of advanced glycation end products in the progression of type II diabetes: a study with aminoguanidine in C57/BLKsJ diabetic mice. Metabolism 47 1477-1480.

Poitout V, Olson LK \& Robertson RP 1996 Chronic exposure of $\beta$ TC-6 cells to supraphysiological concentrations of glucose 
decreases binding of the RIPE3bl insulin gene transcription activator. Fournal of Clinical Investigation 97 1041-1046.

Porte D Jr $1991 \beta$-cells in type II diabetes mellitus. Diabetes 40 166-180.

Purrello F, Vetri M, Gatta C, Gullo D \& Vigneri R 1989 Effects of high glucose on insulin secretion by isolated rat islets and purified beta-cells and possible role of glycosylation. Diabetes 38 1417-1422.

Robertson RP, Zhang HJ, Pyzdrowski KL \& Walseth TF 1992 Preservation of insulin mRNA levels and insulin secretion in HIT cells by avoidance of chronic exposure to high glucose concentrations. Fournal of Clinical Investigation 90 320-325.

Sako Y \& Grill VE 1990 Coupling of $\beta$-cell desentization by hyperglycemia to excessive stimulation and circulating insulin in glucose-infused rats. Diabetes 39 1580-1583.

Schuit FC, Huypens P, Heimberg H \& Pipeleers DG 2001 Glucose sensing in pancreatic beta-cells: a model for the study of other glucose-regulated cells in gut, pancreas, and hypothalamus. Diabetes $\mathbf{5 0} 1-11$.

Steiner DF \& James DE 1992 Cellular and molecular biology of the beta cell. Diabetologia 35 (Suppl 2) S41-S48.

Tajiri Y, Moller C \& Grill V 1997 Long term effects of aminoguanidine on insulin release and biosynthesis: Evidence that the formation of advanced glycation end products inhibits B cell function. Endocrinology 138 273-280.
Terauchi Y, Sakura H, Yasuda K, Iwamoto K, Takahashi N, Ito K, Kasai H, Suzuki H, Ueda O, Kamada N, Jishage K, Komeda K, Noda M, Kanazawa Y, Tanigushi S, Miwa I, Akanuma Y, Kodama T, Yazaki Y \& Kadowaki T 1995 Pancreatic $\beta$-cell-specific targeted disruption of glucokinase gene. Fournal of Biological Chemistry 270 30253-30256.

Tikellis C, Johnston CI, Forbes JM, Burns WC, Burrell LM, Risvanis J \& Cooper ME 2003 Characterization of renal angiotensin-converting enzyme 2 in diabetic nephropathy. Hypertension 41 392-397.

Tikellis C, Wookey PJ, Candido R, Andrikopoulos S, Thomas MC \& Cooper ME 2004 Improved islet morphology following blockade of the renin angiotensin system in the Zucker diabetic fatty rat. Diabetes $\mathbf{5 3}$ 989-997.

Zraika S, Dunlop M, Proietto J \& Andrikopoulos S 2002 The hexosamine biosynthesis pathway regulates insulin secretion via protein glycosylation in mouse islets. Archives of Biochemistry and Biophysics 405 275-279.

Received in final form 19 April 2005

Accepted 21 April 2005

Made available online as an Accepted Preprint 13 May 2005 